Article

\title{
Oxime-Based Carbonates as Useful Reagents for Both $N$-Protection and Peptide Coupling
}

\author{
Yahya El-Sayed Jad ${ }^{1}$, Sherine N. Khattab ${ }^{1}$, Ayman El-Faham ${ }^{1,2,3, *}$ and Fernando Albericio ${ }^{3,4,5,6, *}$
}

1 Department of Chemistry, Faculty of Science, Alexandria University, P.O. Box 426, Ibrahimia, 21321 Alexandria, Egypt

2 Department of Chemistry, College of Science, King Saud University, P.O. Box 2455, 11451 Riyadh, Saudi Arabia

3 Department of Chemistry and Molecular Pharmacology, Institute for Research in Biomedicine, Barcelona Science Park, Baldiri Reixac 10, 08028 Barcelona, Spain

4 CIBER-BBN, Networking Centre on Bioengineering, Biomaterials and Nanomedicine, Barcelona Science Park, Baldiri Reixac 10, 08028 Barcelona, Spain

5 Department of Organic Chemistry, University of Barcelona, Martí i Franqués 1-11, 08028 Barcelona, Spain

6 School of Chemistry, University of KwaZulu-Natal, 4041 Durban, South Africa

* Authors to whom correspondence should be addressed;

E-Mails: aymanel_faham@hotmail.com (A.E.-F.); albericio@irbbarcelona.org (F.A.);

Tel.: +20-122-3140-924 (A.E.-F.); Fax: +20-3-5771-399 (A.E.-F.); Tel./Fax: +34-93-4037-126 (F.A.).

Received: 22 October 2012; in revised form: 23 November 2012 / Accepted: 30 November 2012 / Published: 5 December 2012

\begin{abstract}
We have demonstrated that oxime-based mixed carbonates are very effective reagents for both $N$-protection and peptide coupling.
\end{abstract}

Keywords: oxime; additives; $N$-protection; activation; coupling; peptide

\section{Introduction}

Peptides are increasingly gaining recognition as potential bioactive ingredients in the pharmaceutical industry [1-3]. Peptide synthesis depends on the strategies used for protecting the $\alpha$-amino group and for activating the carboxylic acid group prior to peptide coupling. The two main classes [4-6] of carboxylic acid group activation methods are: (i) those that require in situ activation of the carboxylic 
acid and (ii) those that require an activated species that has previously been prepared (usually from an in situ activation step), isolated, purified, and characterized.

The amino group is most commonly protected by preparing the corresponding carbamate derivative. Despite the vast number of reagents reported to date for introducing the protecting group into the $N$-terminal amino group, there is still no universally active species capable of providing optimal protecting group introduction.

The traditional chloroformate strategy is an extremely powerful approach, providing fast amino group protection [7-9]. Nevertheless, in some cases, presence of the free carboxylic acid group can interfere with the reaction and lead to formation of byproducts such as dipeptides and even tripeptides (Scheme 1) [10].

Scheme 1. Mechanism for the formation side products (dipeptides and tripeptides) during the protection of amino acids with haloformates.

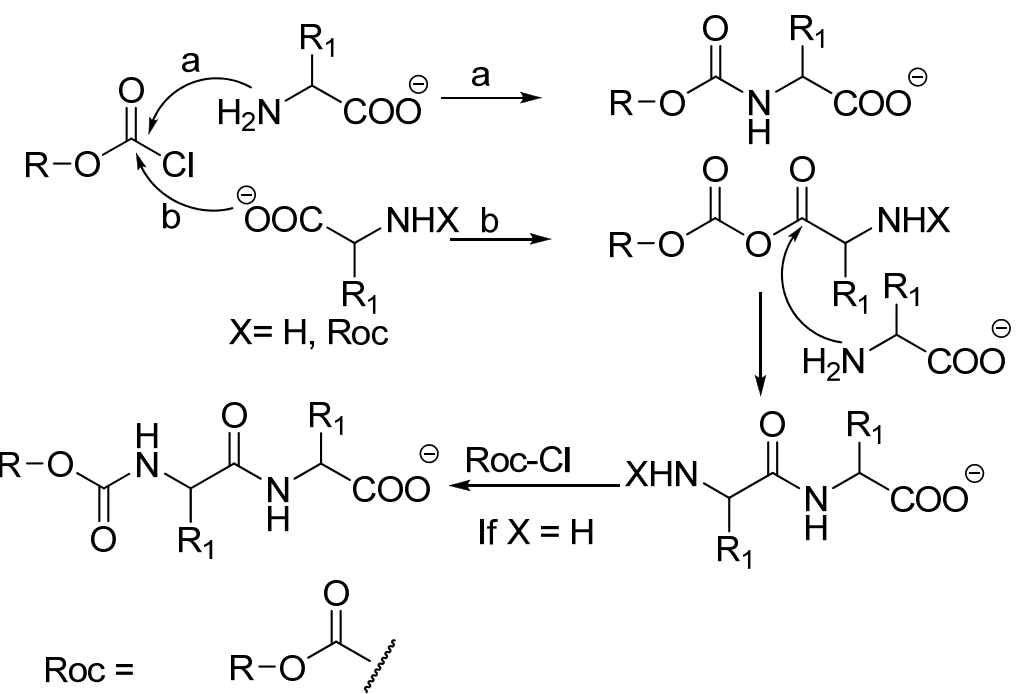

(a): Indicating the $N$-protection by chloroformate; (b): indicating the side reaction which could happen to form the di- and tripeptide.

Since these side-reactions are associated with the quality of the leaving group, the less reactive species such as the dicarbonates 2 (Figure 1) [11-14] and the succinimidocarbonates 3 (Figure 1) [15,16] have previously been proposed as alternatives to the chloride $\mathbf{1}$ (Figure 1). Use of the azide derivatives 4 (Figure 1), [17,18] has also been proposed as an alternative for the chloride to prepare the $\mathrm{N}$-protection of amino acids, but the explosive nature of azides precludes their use in large-scale synthesis. Moreover, several other approaches, based on the use of other less reactive species such as the 1,2,2,2-tetrachloroethyl [19,20], the 5-norbornene-2,3-dicarboximido [21], the pentafluorophenyl [22-24], and the 1-hydroxybenzotriazole [14,25,26] mixed carbonates 5-8 (Figure 1), have been proposed.

Recently, ethyl 2-cyano-2-(hydroxyimino)acetate $\left(\right.$ OxymaPure $\left.^{\circledR}, \mathbf{1 2 a}\right)$ has been tested as an additive for use in the carbodiimide approach for the formation of peptide bonds [27]. OxymaPure ${ }^{\circledR}$ and its uronium-based phosphium coupling reagents displayed a remarkable capacity to inhibit racemization, together with impressive coupling efficiency, in both automated and manual synthesis, superior to those of 12d and which has recently been reported to exhibit explosive properties [26] at least comparable to those of HOAt uronium-based phosphonium coupling reagents [28-34]. 
Later, we reported a series of Fmoc/Alloc-oxime carbonate reagents which are easy to prepare, stable, and highly reactive crystalline materials that afford nearly pure Fmoc/Alloc-amino acids in high yields. Among the Fmoc-oxime carbonates that we evaluated for the preparation of Fmoc/Alloc-Gly-OH, the $\mathrm{N}$-hydroxypicolinimidoyl cyanide derivative 9 (Figure 1) gave the best results [35]. More recently, our research group reported the cyanoacetamide-based oximes 10 (Figure 1), which show unusual ability to afford Fmoc-protected amino acids in high yield, high purity and at lower cost relative to compound 9 [36].

Figure 1. Structure of carbonates derivatives.

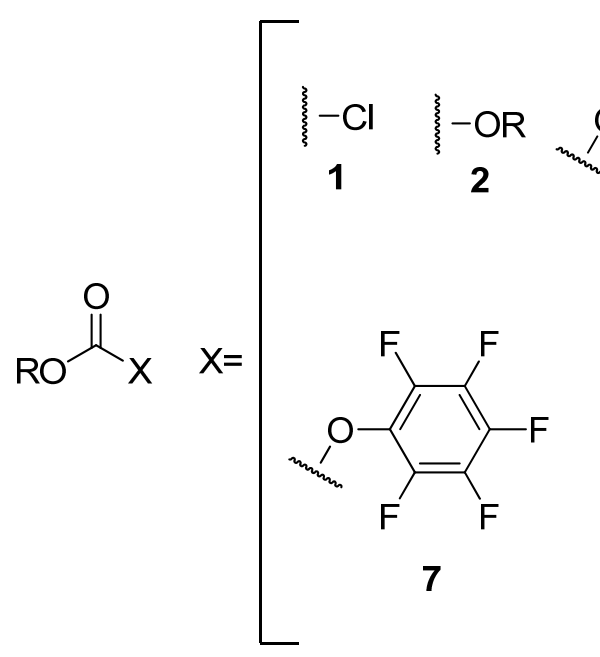<smiles>CCON1C(=O)CCC1=O</smiles><smiles>CCOn1nnc2ccccc21</smiles><smiles>CC(C)ON=C(C#N)c1ccccn1</smiles><smiles>CCON1C(=O)C2C3C=CC(C3)C2C1=O</smiles><smiles>[R]N([R])/C(C#N)=N\OC</smiles><smiles>[18OH]</smiles>

$\mathrm{R}^{1}=\mathrm{R}^{2}=\mathrm{H} \quad 10 \mathrm{a}$

$\mathrm{R}^{1}=\mathrm{H}, \mathrm{R}^{2}=\mathrm{C}_{2} \mathrm{H}_{5} 10 \mathrm{~b}$

$\mathrm{R}^{1}, \mathrm{R}^{2}=\left(\mathrm{CH}_{2}\right)_{5} \quad 10 \mathrm{c}$

$\mathrm{R}^{1}, \mathrm{R}^{2}=\left(\mathrm{CH}_{2}\right)_{4} \mathrm{O} 10 \mathrm{~d}$

Herein, we extended our studies for the synthesis of a new family of carbonate derivatives based on OxymaPure $^{\circledR}$, which are easy to prepare, stable, and have shown high efficiency in $N$-protection as well as peptide coupling.

\section{Results and Discussion}

\subsection{Preparation of Carbonate Derivatives}

The carbonate derivatives $\mathbf{1 3}$ were readily prepared by reacting ethyloxycarbonyl chloride (11) with an oxime (compounds 12a or 12b), $N$-hydroxy-2-pyridinone (12c) or benzotriazole derivatives (HOBt, 12d or $6-\mathrm{Cl}-\mathrm{HOBt}, \mathbf{1 2 f})$ in the presence of sodium carbonate in $\mathrm{DCM} / \mathrm{H}_{2} \mathrm{O}(3: 2)$ as solvent at $0{ }^{\circ} \mathrm{C}$, with stirring at this temperature for $2 \mathrm{~h}$ (Scheme 2). After subsequent workup followed by isolation and recrystallization from $\mathrm{CH}_{2} \mathrm{Cl}_{2}$ /hexane, ethyl 2-cyano-2-(ethoxycarbonyloxyimino)acetate (13a), (ethoxycarbonyloxy)carbonimidoyl dicyanide (13b), ethyl 2-oxopyridin-1(2H)-yl carbonate (13c), $1 H$-benzo[d][1,2,3]triazol-1-yl ethyl carbonate (13d), and 6-chloro-1 $H$-benzo[ $d][1,2,3]$ triazol-1-yl ethyl carbonate (13f), were prepared in 46-78\% yield (Table 1). 
Scheme 2. Preparation of the carbonate derivatives $\mathbf{1 3}$.

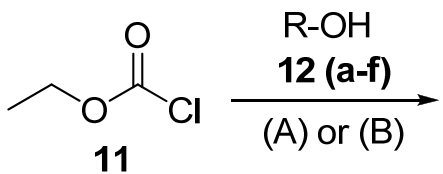<smiles>[R]OC(=O)OCC</smiles><smiles>[R]#CCOC(=O)C(C#N)=NCC</smiles>

a<smiles>CCN=C(C#N)C#N</smiles>

b<smiles>Cn1ccccc1=O</smiles><smiles>CC(Cl)n1nnc2ccccc21</smiles><smiles>CC(C)n1nnc2cccnc21</smiles><smiles>CCn1nnc2ccc(Cl)cc21</smiles>

(A) $=\mathrm{Na}_{2} \mathrm{CO}_{3}, \mathrm{DCM} / \mathrm{H}_{2} \mathrm{O}, 0^{\circ} \mathrm{C} \rightarrow \mathrm{rt}$

(B) $=\mathrm{KOH}, \mathrm{CH}_{3} \mathrm{CN}, 0^{\circ} \mathrm{C} \rightarrow \mathrm{rt}$

Table 1. Yield, m.p. and elemental analysis of the carbonate derivatives 13.

\begin{tabular}{ccccccc}
\hline \multirow{2}{*}{ Compd. } & \multirow{2}{*}{ Method } & \multirow{2}{*}{ Yield (\%) } & \multirow{2}{*}{ m.p. $\left({ }^{\circ} \mathbf{C}\right)$} & \multicolumn{3}{c}{ Elemental Analysis: Calculated (Found) } \\
\cline { 5 - 7 } & & & & $\mathbf{C}$ & $\mathbf{H}$ & $\mathbf{N}$ \\
\hline $\mathbf{1 3 a}$ & $\mathrm{A}$ & 78 & $44-45$ & $44.86(45.08)$ & $4.71(4.63)$ & $13.08(13.17)$ \\
$\mathbf{1 3 b}$ & $\mathrm{A}$ & 69 & oily & $43.12(43.25)$ & $3.02(2.89)$ & $25.14(25.33)$ \\
$\mathbf{1 3 c}$ & $\mathrm{A}$ & 76 & $64-67$ & $52.46(52.21)$ & $4.95(5.16)$ & $7.65(7.91)$ \\
$\mathbf{1 3 d}$ & $\mathrm{A}$ & 52 & $138-139$ & $52.17(51.96)$ & $4.38(4.54)$ & $20.28(20.49)$ \\
$\mathbf{1 3 e} *$ & $\mathrm{~B}$ & 77 & $133-135$ & $46.16(45.88)$ & $3.87(4.14)$ & $26.91(27.19)$ \\
$\mathbf{1 3 f}$ & $\mathrm{A}$ & 76 & $144-145$ & $44.74(44.53)$ & $3.34(3.61)$ & $17.39(17.18)$ \\
\hline
\end{tabular}

* 13e was prepared by reacting ethyloxycarbonyl chloride 11 with HOAt 12e in the presence of anhydrous potassium hydroxide (1 equivalent) in acetonitrile as solvent at $0{ }^{\circ} \mathrm{C}$.

Three different oxime carbonate derivatives: ethyl 2-cyano (isobutoxycarbonyloxyimino)acetate (17), ethyl 2-(allyloxycarbonyloxyimino)-2-cyanoacetate (18) and ethyl 2-(benzyloxycarbonyloxyimino)-2-cyanoacetate (19) were prepared by reacting the corresponding chloroformates 14-16 and OxymaPure $^{\circledR}(\mathbf{1 2 a})$ in the presence of sodium carbonate in $\mathrm{DCM} / \mathrm{H}_{2} \mathrm{O}(3: 2)$ as solvent at $0{ }^{\circ} \mathrm{C}$ (Scheme 3). After subsequent workup followed by isolation and recrystallization from $\mathrm{CH}_{2} \mathrm{Cl}_{2} /$ hexane, the corresponding oxime carbonates 17-19 were obtained in 87-94\% yield (Table 2).

Scheme 3. Preparation of oximinocarbonate derivatives.

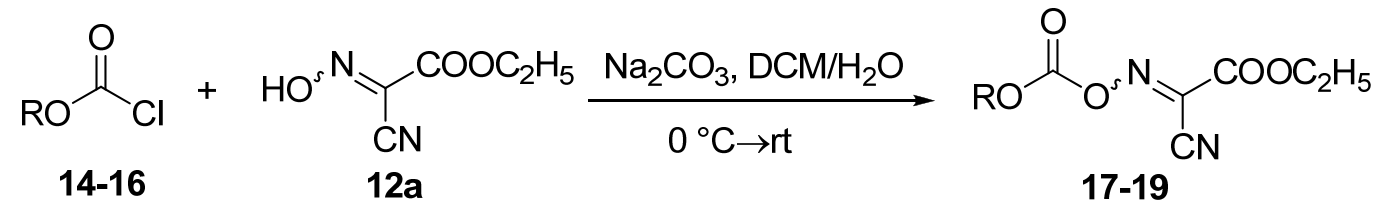

$\mathrm{R}=$ isobutyl 14

$\mathrm{R}=$ allyl 15

$\mathrm{R}=$ isobutyl 17

$\mathrm{R}=$ benzyl 16 
Table 2. Yield, m.p. and elemental analysis of the oximinocarbonate derivatives 17-19.

\begin{tabular}{cccccc}
\hline \multirow{2}{*}{ Product } & \multirow{2}{*}{ Yield (\%) } & \multirow{2}{*}{ m.p. $\left({ }^{\circ} \mathbf{C}\right)$} & \multicolumn{3}{c}{ Elemental Analysis: Calculated (Found) } \\
\cline { 4 - 6 } & & & $\mathbf{C}$ & $\mathbf{H}$ & $\mathbf{N}$ \\
\hline $\mathbf{1 7}$ & 93 & $59-60$ & $49.58(49.81)$ & $5.83(5.57)$ & $11.56(11.74)$ \\
$\mathbf{1 8}$ & 94 & Oily & $47.79(47.93)$ & $4.46(4.61)$ & $12.39(12.58)$ \\
$\mathbf{1 9}$ & 87 & $99-100$ & $56.52(56.23)$ & $4.38(4.62)$ & $10.14(10.41)$ \\
\hline
\end{tabular}

\subsection{Preparation of 4-(Ethoxycarbonylamino)benzoic Acid}

To study the reactivity of prepared carbonate derivatives $\mathbf{1 3 a}-\mathbf{f}$ and their utility for the preparation of the $\mathrm{N}$-protected amino acids, we initiated our studies with 4-aminobenzoic acid (20), which on treatment with the previously synthesized carbonate derivatives 13a-f in a homogenous acetone/aqueous solvent mixture in the presence of sodium carbonate with stirring overnight at room temperature, provides the product 21. Samples of 4-(ethoxycarbonylamino)benzoic acid (21) were obtained from the different carbonate derivatives after removing the unreacted starting carbonate by extracting with ether and acidifying the aqueous layer with $1 \mathrm{~N} \mathrm{HCl}$ (Scheme 4). The purity of the product 21 was determined after injection onto reverse-phase HPLC are shown in Table 3.

Scheme 4. $N$-protection of 4 -aminobenzoic acid using carbonate derivatives $\mathbf{1 3 a}-\mathbf{f}$.

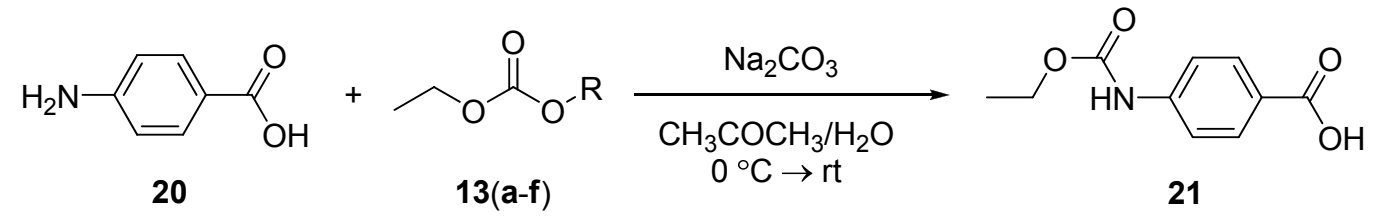

Table 3. Yield \%, m.p., purity \% of 4-(ethoxycarbonylamino)benzoic acid 21.

\begin{tabular}{cccc}
\hline Carbonate & Yield (\%) & m.p. $\left({ }^{\circ} \mathbf{C}\right)$ & Purity * $(\%)$ \\
\hline 13a & 43 & $198-200$ & 95.3 \\
13b & 38 & $199-201$ & 88.5 \\
13c & 59 & $198-200$ & 100 \\
13d & 11 & $184-192$ & 77.1 \\
13e & 31 & $198-202$ & 97.0 \\
13f & 42 & $190-195$ & 83.6 \\
\hline
\end{tabular}

* The purity was determined by HPLC using the following Conditions: detection at $220 \mathrm{~nm}$ (Waters 996 PDA detector); Sunfire $\mathrm{C}_{18}$ column $(3.5 \mu \mathrm{m} 4.6 \times 100 \mathrm{~mm})$; linear gradient over $14 \mathrm{~min}\left(10\right.$ to $100 \% \mathrm{CH}_{3} \mathrm{CN}$ in $\mathrm{H}_{2} \mathrm{O} / 0.1 \% \mathrm{TFA}$ ); flow rate $1.0 \mathrm{~mL} / \mathrm{min} . t_{\mathrm{R}}$ [4-(ethoxycarbonylamino)benzoic acid] $=4.18 \mathrm{~min}$.

Table 3 showed that, $1 H$-benzo $[d][1,2,3]$ triazol-1-yl ethyl carbonate (13d) provided the lowest purity $(77.1 \%)$ and yield (11\%) of all the ethoxycarbonyl carbonate derivatives. (Ethoxycarbonyloxy) carbonimidoyl dicyanide (13b) and 6-chloro-1H-benzo $[d][1,2,3]$ triazol-1-yl ethyl carbonate (13f) provided moderate levels of purity $(88.5 \%$ and $83.6 \%)$ and yield (38\% and $42 \%)$. Ethyl 2-cyano-2(ethoxycarbonyloxyimino)acetate (13a) and $3 H$-[1,2,3]triazolo[4,5-b]pyridin-3-yl ethyl carbonate (13e) provided high purity ( $95.3 \%$ and $97.0 \%$, respectively) and moderate yield ( $43 \%$ and $31 \%$ ), while, 
ethyl 2-oxopyridin-1(2H)-yl carbonate (13c) provided the highest yield (59\%) with excellent purity $(100 \%)$ as indicated from the HPLC traces.

\subsection{HPLC Study of the Rate of Formation of the Active Ester}

Before attempting simultaneous protection and activation of amino acids, we tried to prepare active esters of $N$-protected amino acids using the carbonate derivatives 13a, 17, 18, and 19 to ensure that these compounds can activate carboxylic acids by forming the corresponding active ester for different Fmoc-amino acids. The reaction of Fmoc-amino acids with oxime carbonate derivatives was monitored by HPLC to study the rate of formation of the active ester. Aliquots $(5 \mu \mathrm{L})$ of the reaction mixture were taken, diluted with acetonitrile, and then analyzed by HPLC. Follow-up samples were studied at intervals of time $30 \mathrm{~min}$ and 1, 2, 4 and $24 \mathrm{~h}$ pre-activation. This enabled us to determine the optimum pre-activation time for each carbonate reagent, as excessively long times could lead to greater formation of alkyl or aryl esters.

\subsubsection{The Rate of Formation of the Active Ester of Fmoc-Val-OH Using Oxime Carbonate Derivatives}

Mixing of Fmoc-Val-OH 22 with the oxime carbonate reagents EtocOXY 13a, ${ }^{i}$ BuocOXY 17, AllocOXY 18 and ZOXY 19 in the presence of pyridine in DMF, we observed maximum levels of the active ester was formed at $4 \mathrm{~h}$ for 13a, $2 \mathrm{~h}$ for 17, $30 \mathrm{~min}$ for $\mathbf{1 8}$ and $1 \mathrm{~h}$ for $\mathbf{1 9}$. Whereas the alkyl or aryl esters 26 started to be formed after 2 and $1 \mathrm{~h}$ in case of EtocOXY 13a and ${ }^{i}$ BuocOXY 17, respectively, and after half an hour in case of AllocOXY 18 and ZOXY 19 respectively. Therefore, the optimum pre-activation time should not exceed more than 2 and $1 \mathrm{~h}$ in case of EtocOXY 13a and ${ }^{i}$ BuocOXY 17, respectively, and should be less than half an hour in case of both AllocOXY 18 and ZOXY 19 systems. Best results for formation of the active ester were obtained with the oxime carbonate 17 and 18, while the oxime carbonates 13a and 19 gave high yield of the alkyl ester (Tables 4-7).

Table 4. The rate of formation of the active ester of Fmoc-Val-OH 22 using ethyl 2-cyano2-(ethoxycarbonyloxyimino)acetate (13a).

\begin{tabular}{ccccc}
\hline Pre-activation time (hr) & Oxyma 12a & Fmoc-Val-OH 22 & Active ester 27 & Ethyl ester \\
\hline $1 / 2$ & 7.2 & 40.6 & 37.8 & $\mathrm{n} / \mathrm{a}$ \\
1 & 3.7 & 48.0 & 39.8 & $\mathrm{n} / \mathrm{a}$ \\
2 & 2.3 & 29.5 & 61.7 & $\mathrm{n} / \mathrm{a}$ \\
4 & 3.5 & 18.7 & 61.1 & 13.2 \\
24 & 19.1 & 17.4 & 15.0 & 48.5 \\
\hline
\end{tabular}

Table 5. The rate of formation of the active ester of Fmoc-Val-OH 22 using ethyl 2-cyano2-(isobutoxycarbonyloxyimino)acetate (17).

\begin{tabular}{ccccc}
\hline Pre-activation time (hr) & Oxyma 12a & Fmoc-Val-OH 22 & Active ester 27 & Isobutyl ester \\
\hline $1 / 2$ & 3.1 & 54.7 & 33.6 & $\mathrm{n} / \mathrm{a}$ \\
1 & 0.9 & 45.9 & 44.3 & $\mathrm{n} / \mathrm{a}$ \\
2 & 1.4 & 37.2 & 54.8 & 1.9 \\
4 & 2.6 & 27.3 & 63.5 & 6.7 \\
24 & 16.8 & 16.0 & 21.9 & 45.3 \\
\hline
\end{tabular}


Table 6. The rate of formation of the active ester of Fmoc-Val-OH 22 using ethyl 2-(allyloxycarbonyloxyimino)-2-cyanoacetate (18).

\begin{tabular}{ccccc}
\hline Pre-activation time (hr) & Oxyma 12a & Fmoc-Val-OH 22 & Active ester 27 & Allyl ester \\
\hline $1 / 2$ & $\mathrm{n} / \mathrm{a}$ & 9.4 & 63.9 & 10.8 \\
1 & $\mathrm{n} / \mathrm{a}$ & 14.2 & 58.1 & 3.7 \\
2 & $\mathrm{n} / \mathrm{a}$ & 5.7 & 73.0 & 6.1 \\
4 & 23.6 & 2.8 & 55.9 & $\mathrm{n} / \mathrm{a}$ \\
\hline
\end{tabular}

Table 7. The rate of formation of the active ester of Fmoc-Val-OH 22 using ethyl 2-(benzyloxycarbonyloxyimino)-2-cyanoacetate (19).

\begin{tabular}{ccccc}
\hline Pre-activation time (hr) & Oxyma 12a & Fmoc-Val-OH 22 & Active ester 27 & Benzyl ester \\
\hline $1 / 2$ & 1.5 & 40.4 & 52.5 & $\mathrm{n} / \mathrm{a}$ \\
1 & 3.4 & 28.1 & 53.7 & 7.5 \\
2 & 6.9 & 19.0 & 48.4 & 13.1 \\
4 & 11.6 & 14.1 & 32.2 & 20.2 \\
24 & 22.1 & 14.1 & 2.1 & 31.4 \\
\hline
\end{tabular}

2.3.2. The Rate of Formation of the Active Ester of Fmoc-Phe-OH Using Oxime Carbonate Derivatives

Due to the best results obtained from the previous example with the oxime carbonate derivatives $\mathbf{1 7}$ and 18, Fmoc-Phe-OH 23 was tested with ${ }^{i}$ BuocOXY 17 and AllocOXY 18 under the same conditions used in the previous example. From the results obtained from HPLC monitoring, the maximum levels of the active ester $\mathbf{2 7}$ are formed from the oxime carbonate derivatives $\mathbf{1 7}$ and $\mathbf{1 8}$ at 1 and $2 \mathrm{~h}$, respectively; while the alkyl esters 26 appeared after 30 min and 1 hour, respectively. Thus, the pre-activation time in both systems should not exceed more than 30 min (Tables 8 and 9).

Table 8. The rate of formation of the active ester of Fmoc-Phe-OH 23 using ethyl 2-cyano-2-(isobutoxycarbonyloxyimino)acetate (17).

\begin{tabular}{ccccc}
\hline Pre-activation time (hr) & Oxyma 12a & Fmoc-Phe-OH 23 & Active ester 27 & Isobutyl ester \\
\hline $1 / 2$ & $\mathrm{n} / \mathrm{a}$ & 28.3 & 43.0 & 14.7 \\
1 & 0.8 & 15.8 & 72.0 & 8.4 \\
2 & 0.5 & 19.5 & 58.2 & 6.1 \\
4 & 0.8 & 16.2 & 63.3 & 1.5 \\
24 & 3.5 & 21.4 & 52.7 & 22.0 \\
\hline
\end{tabular}

Table 9. The rate of formation of the active ester of Fmoc-Phe-OH 23 using ethyl 2-(allyloxycarbonyloxyimino)-2-cyanoacetate (18).

\begin{tabular}{ccccc}
\hline Pre-activation time (hr) & Oxyma 12a & Fmoc-Phe-OH 23 & Active ester 27 & Allyl ester \\
\hline $1 / 2$ & 4.7 & 24.7 & 58.56 & \\
1 & 4.6 & 22.3 & 65.9 & 0.4 \\
2 & 5.5 & 12.6 & 74.6 & 0.6 \\
4 & 5.8 & 19.2 & 68.3 & 0.4 \\
24 & 13.5 & 4.6 & 53.4 & 25.4 \\
\hline
\end{tabular}


2.3.3. The Rate of Formation of the Active Ester of Fmoc-Pro-OH Using Oxime Carbonate Derivatives

To ensure that we will get the same results with the oxime carbonate derivatives $\mathbf{1 7}$ and $\mathbf{1 8}$, further study was performed with the more sterically hindered amino acid Fmoc-Pro-OH 24 using the two carbonate derivatives ${ }^{i}$ BuocOXY 17 and AllocOXY 18. From the results obtained by HPLC monitoring, we observed the maximum levels of the active ester 27 after 30 min and $2 \mathrm{~h}$, respectively; while the alkyl esters $\mathbf{2 6}$ appeared after $30 \mathrm{~min}$ and 1 hour, respectively. Thus, the pre-activation time in both systems should not exceed more than $30 \mathrm{~min}$, which in agreement with the previous results (Tables 10 and 11).

Table 10. The rate of formation of the active ester of Fmoc-Pro-OH 24 using ethyl 2-Cyano-2-(isobutoxycarbonyloxyimino)acetate (17).

\begin{tabular}{ccccc}
\hline Pre-activation time (hr) & Oxyma 12a & Fmoc-Pro-OH 24 & Active ester 27 & Isobutyl ester \\
\hline $1 / 2$ & 0.2 & 13.4 & 59.8 & 5.0 \\
1 & 1.6 & 47.4 & 34.1 & 6.7 \\
2 & 1.3 & 30.7 & 53.9 & 3.1 \\
4 & 1.6 & 30.8 & 55.8 & 3.8 \\
24 & 17.8 & 75.9 & 6.3 & $\mathrm{n} / \mathrm{a}$ \\
\hline
\end{tabular}

Table 11. The rate of formation of the active ester of Fmoc-Pro-OH 24 using ethyl 2-(allyloxycarbonyloxyimino)-2-cyanoacetate (18).

\begin{tabular}{ccccc}
\hline Pre-activation time (hr) & Oxyma 12a & Fmoc-Pro-OH 24 & Active ester 27 & Allyl ester \\
\hline $1 / 2$ & 1.4 & 13.2 & 65.7 & $\mathrm{n} / \mathrm{a}$ \\
1 & 1.8 & 13.3 & 70.3 & 2.8 \\
2 & 3.0 & 15.2 & 70.6 & 2.7 \\
4 & 13.8 & 58.0 & 24.3 & 3.9 \\
24 & 19.4 & 46.7 & 18.7 & 15.2 \\
\hline
\end{tabular}

The results obtained from Tables 4-11 may indicate that, the activation of carboxylic acid group of the amino acid using oximinocarbonate derivatives may proceed through a mixed anhydride-type intermediate 25, which may react with the oxyma anion to afford the active ester 27 (Scheme 5). Its decarboxylation will afford alkyl or aryl esters 26, which is a rather slow step. All intermediate stages of the reaction are run at low temperature to prevent side reactions.

Scheme 5. Mechanism of the formation of the oxime active ester using oxyme carbonates.

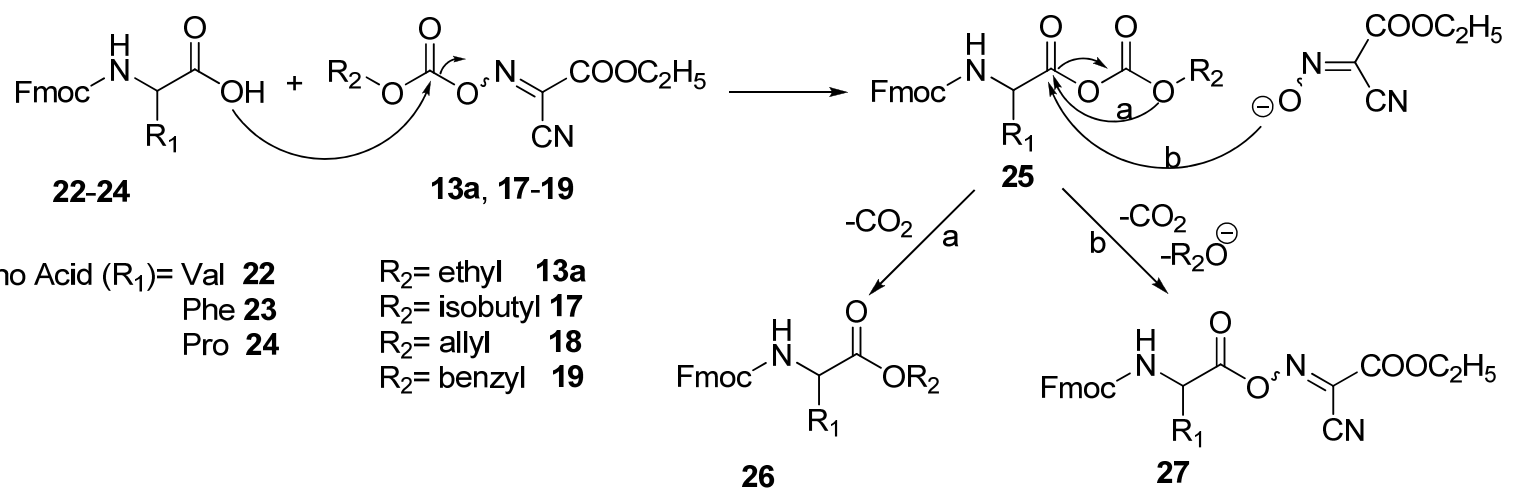




\subsection{Synthesis of Dipeptide Fmoc-Val-Ala-OMe}

As an initial model to examine the reactivity of the oxime carbonate 13a, 17, 18 and 19 as coupling reagents, these reagents were examined in the stepwise coupling of a previously studied model system [29] Fmoc-Val-Ala-OMe 28. The pre-activation time was determined for each of these coupling reagents according to the previous studies obtained from HPLC for the rate of formation of active ester. All coupling reactions were performed in the presence of 2 equiv. pyridine as a base and in DMF as solvent. The results for each coupling reagent are given in Table 12.

Table 12. Coupling of Fmoc-Val-OH with H-Ala-OMe 28 using different oxime carbonate derivatives.

\begin{tabular}{ccccc}
\hline Coupling reagent & Pre-activation time (hr) & m.p. $\left({ }^{\circ} \mathbf{C}\right)$ & Yield (\%) & HPLC Purity (\%) \\
\hline EtocOXY 13a & 2 & $195-196$ & 77 & 100 \\
${ }^{i}$ BuocOXY 17 & 1 & $192-193$ & 54 & 96.1 \\
AllocOXY 18 & $1 / 2$ & $194-195$ & 75 & 98.7 \\
ZOXY 19 & $1 / 2$ & $194-195$ & 64 & 97.7 \\
\hline
\end{tabular}

The purity of the dipeptide $\mathbf{2 8}$ was determined by HPLC, and was found to be 96.1 to $100 \%$ at $t_{\mathrm{R} \text { LL }}[$ Fmoc-Val-Ala-OMe] $=8.32 \mathrm{~min}$. From Table 12, the highest yield and purity was obtained with EtocOXY 13a, while the lowest yield and purity was obtained with ${ }^{i}$ BuocOXY 17 and ZOXY 19. While, the AllocOXY 18 had moderate yield and purity. None of the D,L-isomer was detected by HPLC or NMR spectra in all the cases, but the impurities were related to the alkyl ester and oxime.

\section{Experimental}

\subsection{Materials}

The solvents used were of HPLC reagent grade. Melting points were determined with a Mel-Temp apparatus and are uncorrected. Infrared (IR) spectra were recorded on a Perkin-Elmer 1600 series Fourier transform instrument as $\mathrm{KBr}$ pellets. Nuclear Magnetic resonance spectra $\left({ }^{1} \mathrm{H}-\mathrm{NMR}\right.$ and ${ }^{13} \mathrm{C}-\mathrm{NMR}$ spectra) were recorded on a JOEL $500 \mathrm{MHz}$ and on a Mercury $400 \mathrm{MHz}$ spectrometer with chemical shift values reported in $\delta$ units (ppm) relative to an internal standard. Elemental analyses were performed on Perkin-Elmer 2400 elemental analyzer, and the values found were within $\pm 0.3 \%$ of the theoretical values. Follow-up of the reactions and checks of the purity of the compounds was done by TLC on silica gel-protected aluminum sheets (Type 60 GF254, Merck, Barcelona, Spain) and the spots were detected by exposure to UV-lamp at $\lambda 254 \mathrm{~nm}$ for a few seconds. The compounds were named using ChemDraw Ultra version 11, CambridgeSoft Corporation (Cambridge, MA, USA).

\subsection{General Method for Preparation of Ethyloxycarbonyl Derivatives $\mathbf{1 3}(\mathbf{a}-\mathbf{d}, \mathbf{f})$}

A solution of ethyloxycarbonyl chloride $(\mathbf{1 1}, 0.95 \mathrm{~mL}, 10 \mathrm{mmol})$ in $\mathrm{CH}_{2} \mathrm{Cl}_{2}(30 \mathrm{~mL})$ was added slowly to a solution of sodium carbonate $(2.12 \mathrm{~g}, 20 \mathrm{mmol})$ and $10 \mathrm{mmol}$ of oximes (12a, 12b), 1-hydroxypyridin-2(1H)-one (12c), or benzotriazole derivatives (12d or 12f) in $\mathrm{H}_{2} \mathrm{O}(20 \mathrm{~mL})$ with stirring at $0{ }^{\circ} \mathrm{C}$. The resulting clear mixture was stirred at $0^{\circ} \mathrm{C}$ for $30 \mathrm{~min}$ and then at room temperature for $2 \mathrm{~h}$. After dilution with $\mathrm{CH}_{2} \mathrm{Cl}_{2}(50 \mathrm{~mL})$, the organic phase was collected and washed with water 
and saturated aqueous $\mathrm{NaCl}(30 \mathrm{~mL})$, dried over anhydrous $\mathrm{Na}_{2} \mathrm{SO}_{4}$ and then filtered, and the solvent was then removed on a rotary evaporator. The residue was recrystallized from $\mathrm{CH}_{2} \mathrm{Cl}_{2}$ /hexane to give the ethyloxycarbonyl derivatives $\mathbf{1 3}(\mathbf{a}-\mathbf{d}, \mathbf{f})$.

Ethyl 2-cyano-2-(ethoxycarbonyloxyimino)acetate (13a). The product was obtained as white crystals (1.67 g; 78.17\% yield) (m.p. 44-45 ${ }^{\circ} \mathrm{C}$ ). IR (KBr): 2241 (w, CN), 1812 (s, CO), 1741 (s, CO, ester) $\mathrm{cm}^{-1} .{ }^{1} \mathrm{H}-\mathrm{NMR}\left(\mathrm{CDCl}_{3}\right): \delta$ 1.39-1.41 (m, 6H, $\left.2 \mathrm{CH}_{3}\right), 4.43-4.47\left(\mathrm{~m}, 4 \mathrm{H}, 2 \mathrm{CH}_{2}\right) .{ }^{13} \mathrm{C}-\mathrm{NMR}\left(\mathrm{CDCl}_{3}\right): \delta$ 14.14, 14.26, 64.76, 67.33, 106.67, 131.03, 150.87, 156.81. Elemental analysis Calcd for $\mathrm{C}_{8} \mathrm{H}_{10} \mathrm{~N}_{2} \mathrm{O}_{5}$ : C, 44.86; H, 4.71; N, 13.08. Found: C, 45.08; H, 4.63; N, 13.17.

(Ethoxycarbonyloxy)carbonimidoyl dicyanide (13b). The product was obtained as an oil at room temperature (1.15 g; 68.89\% yield). IR ( $\mathrm{KBr}): 2248$ (w, CN), 1811 (s, CO, ester) $\mathrm{cm}^{-1}$. ${ }^{1} \mathrm{H}-\mathrm{NMR}$ $\left(\mathrm{CDCl}_{3}\right): \delta 1.43\left(\mathrm{t}, 3 \mathrm{H},{ }^{3} J=7.2 \mathrm{~Hz}, \mathrm{CH}_{3}\right), 4.49\left(\mathrm{q}, 2 \mathrm{H},{ }^{3} J=7.2 \mathrm{~Hz}, \mathrm{CH}_{2}\right) .{ }^{13} \mathrm{C}-\mathrm{NMR}\left(\mathrm{CDCl}_{3}\right): \delta 14.18$, 68.32, 104.81, 108.03, 114.44, 149.70. Elemental analysis: Calcd for $\mathrm{C}_{6} \mathrm{H}_{5} \mathrm{~N}_{3} \mathrm{O}_{3}: \mathrm{C}, 43.12 ; \mathrm{H}, 3.02 ; \mathrm{N}$, 25.14. Found: C, 43.25; H, 2.89; N, 25.33.

Ethyl 2-oxopyridin-1(2H)-yl carbonate (13c). The product was obtained as white crystals (1.38 g; 75.47\% yield) (m.p. $64-67{ }^{\circ} \mathrm{C}$ ). IR ( $\mathrm{KBr}$ ): 1792 (s, CO), 1668 (s, CO, amidic) cm ${ }^{-1} .{ }^{1} \mathrm{H}-\mathrm{NMR}\left(\mathrm{CDCl}_{3}\right): \delta$ $1.42\left(\mathrm{t}, 3 \mathrm{H},{ }^{3} \mathrm{~J}=7.2 \mathrm{~Hz}, \mathrm{CH}_{3}\right), 4.42\left(\mathrm{q}, 2 \mathrm{H},{ }^{3} \mathrm{~J}=7.2 \mathrm{~Hz}, \mathrm{CH}_{2}\right), 6.20\left(\mathrm{td}, 1 \mathrm{H},{ }^{3} J=6.8 \mathrm{~Hz},{ }^{4} \mathrm{~J}=1.6 \mathrm{~Hz}\right.$, Py-H), 6.72-6.74 (m, 1H, Py-H), $7.36\left(\mathrm{td}, 1 \mathrm{H},{ }^{3} J=6.8 \mathrm{~Hz},{ }^{4} \mathrm{~J}=2 \mathrm{~Hz}, \mathrm{Py}-\mathrm{H}\right), 7.46\left(\mathrm{dd}, 1 \mathrm{H},{ }^{3} J=6.8 \mathrm{~Hz}\right.$, $\left.{ }^{4} J=2 \mathrm{~Hz}, \mathrm{Py}-\mathrm{H}\right) .{ }^{13} \mathrm{C}-\mathrm{NMR}\left(\mathrm{CDCl}_{3}\right): \delta 14.25,67.53,105.29,123.18,135.14,139.69,152.45,157.31$.

1H-Benzo[d][1,2,3]triazol-1-yl ethyl carbonate (13d). The product was obtained as white crystals (1.07 g; $51.84 \%$ yield) (m.p. $\left.138-139{ }^{\circ} \mathrm{C}\right)$. IR $(\mathrm{KBr}): 1751(\mathrm{~s}, \mathrm{CO}) \mathrm{cm}^{-1} \cdot{ }^{1} \mathrm{H}-\mathrm{NMR}\left(\mathrm{CDCl}_{3}\right): \delta 1.53(\mathrm{t}, 3 \mathrm{H}$, $\left.{ }^{3} J=7.2 \mathrm{~Hz}, \mathrm{CH}_{3}\right), 4.63\left(\mathrm{q}, 2 \mathrm{H},{ }^{3} J=7.2 \mathrm{~Hz}, \mathrm{CH}_{2}\right), 7.56\left(\mathrm{td}, 1 \mathrm{H},{ }^{3} \mathrm{~J}=8.4 \mathrm{~Hz},{ }^{4} \mathrm{~J}=0.8 \mathrm{~Hz}, \mathrm{Ar}-\mathrm{H}\right), 7.78$ (td, $\left.1 \mathrm{H},{ }^{3} J=8.4 \mathrm{~Hz},{ }^{4} J=1.2 \mathrm{~Hz}, \mathrm{Ar}-\mathrm{H}\right), 8.00\left(\mathrm{~d}, 1 \mathrm{H},{ }^{3} J=8.4 \mathrm{~Hz}, \mathrm{Ar}-\mathrm{H}\right), 8.21\left(\mathrm{~d}, 1 \mathrm{H},{ }^{3} J=8.4 \mathrm{~Hz}, \mathrm{Ar}-\mathrm{H}\right)$. ${ }^{13} \mathrm{C}-\mathrm{NMR}\left(\mathrm{CDCl}_{3}\right): \delta=14.42,65.67,115.27,115.88,126.46,132.91,133.54,147.52$. Elemental analysis: Calcd for $\mathrm{C}_{9} \mathrm{H}_{9} \mathrm{~N}_{3} \mathrm{O}_{3}$ : C, 52.17; H, 4.38; N, 20.28. Found: C, 51.96; H, 4.54; N, 20.49.

6-Chloro-1H-benzo[d] [1,2,3]triazol-1-yl ethyl carbonate (13f). The product was obtained as white crystals (1.81 g; 75.67\% yield) (m.p. $\left.144-145^{\circ} \mathrm{C}\right)$. IR (KBr): $1743(\mathrm{~s}, \mathrm{CO}) \mathrm{cm}^{-1} .{ }^{1} \mathrm{H}-\mathrm{NMR}\left(\mathrm{CDCl}_{3}\right): \delta$ $1.53\left(\mathrm{t}, 3 \mathrm{H},{ }^{3} J=7.2 \mathrm{~Hz}, \mathrm{CH}_{3}\right), 4.62\left(\mathrm{q}, 2 \mathrm{H},{ }^{3} J=7.2 \mathrm{~Hz}, \mathrm{CH}_{2}\right), 7.72\left(\mathrm{dd}, 1 \mathrm{H},{ }^{3} J=8.8 \mathrm{~Hz},{ }^{4} J=2 \mathrm{~Hz}, \mathrm{Ar}-\mathrm{H}\right)$, $8.00\left(\mathrm{~d}, 1 \mathrm{H},{ }^{4} \mathrm{~J}=2 \mathrm{~Hz}, \mathrm{Ar}-\mathrm{H}\right), 8.16\left(\mathrm{~d}, 1 \mathrm{H},{ }^{3} \mathrm{~J}=8.8 \mathrm{~Hz}, \mathrm{Ar}-\mathrm{H}\right) .{ }^{13} \mathrm{C}-\mathrm{NMR}\left(\mathrm{CDCl}_{3}\right): \delta 14.42,65.99$, 115.70, 116.32, 132.19, 132.81, 133.78, 147.32. Elemental analysis: Calcd for $\mathrm{C}_{9} \mathrm{H}_{8} \mathrm{ClN}_{3} \mathrm{O}_{3}: \mathrm{C}, 44.74$; H, 3.34; N, 17.39. Found: C, 44.53; H, 3.61; N, 17.18.

\subsection{H-[1,2,3]Triazolo[4,5-b]pyridin-3-yl Ethyl Carbonate (13e)}

A solution of HOAt (12e, $0.68 \mathrm{~g}, 5 \mathrm{mmol})$ and anhydrous potassium hydroxide $(0.3 \mathrm{~g}, 5.5 \mathrm{mmol})$ in acetonitrile $(5 \mathrm{~mL})$ was cooled to $0{ }^{\circ} \mathrm{C}$. A solution of ethyloxycarbonyl chloride $(\mathbf{1 1}, 0.47 \mathrm{~mL}, 5 \mathrm{mmol})$ in acetonitrile $(5 \mathrm{~mL})$ was slowly added dropwise for $30 \mathrm{~min}$ to the solution as it was stirred magnetically. The resulting clear mixture was stirred at room temperature overnight. It was then filtered, and the solvent was removed with a rotary evaporator. The residue was recrystallized from $\mathrm{CH}_{2} \mathrm{Cl}_{2} /$ hexane to give $3 \mathrm{H}$-[1,2,3]triazolo[4,5-b]pyridin-3-yl ethyl carbonate (13e). The product was 
obtained as $0.8 \mathrm{~g}\left(77.14 \%\right.$ yield) of white crystals (m.p. $\left.133-135{ }^{\circ} \mathrm{C}\right)$. IR (KBr): $1744(\mathrm{~s}, \mathrm{CO}) \mathrm{cm}^{-1}$. ${ }^{1} \mathrm{H}-\mathrm{NMR}$ (DMSO): $\delta 1.05$ (t, 3H, $\left.{ }^{3} J=7.2 \mathrm{~Hz}, \mathrm{CH}_{3}\right), 3.43\left(\mathrm{q}, 2 \mathrm{H},{ }^{3} J=7.2 \mathrm{~Hz}, \mathrm{CH}_{2}\right), 7.49-7.53(\mathrm{~m}, 1 \mathrm{H}$, Ar-H), 8.52-8.55 (m, 1H, Ar-H), 8.75-8.77 (m, 1H, Ar-H), ${ }^{13} \mathrm{C}-\mathrm{NMR}$ (DMSO): $\delta 18.47,55.94$, 120.62, 124.09, 134.52, 139.50, 151.01. Elemental analysis: Calcd for $\mathrm{C}_{8} \mathrm{H}_{8} \mathrm{~N}_{4} \mathrm{O}_{3}$ : C, 46.16; $\mathrm{H}, 3.87$; N, 26.91. Found: C, 45.88; H, 4.14; N, 27.19.

\subsection{General Method for Preparation of Oxime Carbonate Derivatives 17-19}

A solution of chloroformate $(10 \mathrm{mmol})$ [isobutyloxycarbonyl chloride (14), allyloxycarbonyl chloride (15) or benzyloxycarbonyl chloride (16)] in $\mathrm{CH}_{2} \mathrm{Cl}_{2}(30 \mathrm{~mL})$ was added slowly to a solution (10 mmol) of oxima 12a and sodium carbonate $(2.12 \mathrm{~g}, 20 \mathrm{mmol})$ in $\mathrm{H}_{2} \mathrm{O}(20 \mathrm{~mL})$ with stirring at $0{ }^{\circ} \mathrm{C}$. The resulting clear mixture was stirred at $0{ }^{\circ} \mathrm{C}$ for $30 \mathrm{~min}$ and then at room temperature for $2 \mathrm{~h}$. After dilution with $\mathrm{CH}_{2} \mathrm{Cl}_{2}(50 \mathrm{~mL})$, the organic phase was collected, washed with water and saturated aqueous $\mathrm{NaCl}(30 \mathrm{~mL})$, and then dried over anhydrous $\mathrm{MgSO}_{4}$. It was then filtered, and the solvent was removed with a rotary evaporator. The residue was recrystallized from $\mathrm{CH}_{2} \mathrm{Cl}_{2}$ /hexane to give oxime carbonate derivatives 17-19.

Ethyl 2-cyano-2-(isobutoxycarbonyloxyimino)acetate (17). The product was obtained as a white solid (2.42 g; 93\% yield) (m.p. 59-60 ${ }^{\circ} \mathrm{C}$ ). IR (KBr): 1814 (s, CO), 1758 (s, CO, ester) $\mathrm{cm}^{-1}$. ${ }^{1} \mathrm{H}-\mathrm{NMR}$ $\left(\mathrm{CDCl}_{3}\right): \delta 1.00\left(\mathrm{~d}, J=6.8 \mathrm{~Hz}, 6 \mathrm{H}, 2 \mathrm{CH}_{3}\right), 1.42\left(\mathrm{t}, J=7.2 \mathrm{~Hz}, 3 \mathrm{H}, \mathrm{CH}_{3}\right), 2.06-2.13(\mathrm{~m}, 1 \mathrm{H}, \mathrm{CH}), 4.17$ $\left(\mathrm{d}, J=6.4 \mathrm{~Hz}, 2 \mathrm{H}, \mathrm{CH}_{2}\right), 4.50$ (q, $\left.J=7.2 \mathrm{~Hz}, 2 \mathrm{H}, \mathrm{CH}_{2}\right) .{ }^{13} \mathrm{C}-\mathrm{NMR}\left(\mathrm{CDCl}_{3}\right): \delta 14.16,18.89,27.95$, 64.75, 106.70, 130.97, 151.10, 156.84. Elemental analysis: Calcd for $\mathrm{C}_{10} \mathrm{H}_{14} \mathrm{~N}_{2} \mathrm{O}_{5}$ : C, 49.58; H, 5.83; N, 11.56. Found: C, 49.81; H, 5.57; N, 11.74. The purity of $\mathbf{1 7}$ was determined after injection onto reverse-phase HPLC. Conditions: detection at $254 \mathrm{~nm}$ Waters 996 PDA detector, Sunfire $\mathrm{C}_{18}$ column $3.5 \mu \mathrm{m} 4.6 \times 100 \mathrm{~mm}$, linear gradient over $14 \mathrm{~min}$ of 10 to $100 \% \mathrm{CH}_{3} \mathrm{CN}$ in $\mathrm{H}_{2} \mathrm{O} / 0.1 \%$ TFA, flow rate $1.0 \mathrm{~mL} / \mathrm{min}$. $t_{\mathrm{R}}$ [ethyl 2-cyano-2-(isobutoxycarbonyloxyimino)acetate] $=7.38 \mathrm{~min}$; purity $100 \%$.

Ethyl 2-(allyloxycarbonyloxyimino)-2-cyanoacetate (18). The product was obtained as an oily substance that solidified in the refrigerator (2.26 g; 94\% yield). IR (KBr): 2211 (w, CN), 1809 (s, CO), 1758 (s, CO, ester) $\mathrm{cm}^{-1} .{ }^{1} \mathrm{H}-\mathrm{NMR}\left(\mathrm{CDCl}_{3}\right): \delta 1.42\left(\mathrm{t}, 3 \mathrm{H},{ }^{3} \mathrm{~J}=7.2 \mathrm{~Hz}, \mathrm{CH}_{3}\right), 4.48\left(\mathrm{q}, 2 \mathrm{H},{ }^{3} \mathrm{~J}=7.2 \mathrm{~Hz}\right.$, $\left.\mathrm{CH}_{2}\right), 4.85-4.87\left(\mathrm{~m}, 2 \mathrm{H}, \mathrm{CH}_{2}\right), 5.39-5.51\left(\mathrm{~m}, 2 \mathrm{H}, \mathrm{CH}_{2}\right), 5.96-6.03(\mathrm{~m}, 1 \mathrm{H}, \mathrm{CH}) .{ }^{13} \mathrm{C}-\mathrm{NMR}\left(\mathrm{CDCl}_{3}\right): \delta$ $14.11,64.78,71.23,106.62,121.27,130.07,131.24,150.74,156.73$. Elemental analysis. Calcd for $\mathrm{C}_{9} \mathrm{H}_{10} \mathrm{~N}_{2} \mathrm{O}_{5}$ : C, 47.79; H, 4.46; N, 12.39. Found: C, 47.93; H, 4.61; N, 12.58. The purity of 18 was determined after injection onto reverse-phase HPLC. Conditions: detection at $254 \mathrm{~nm}$ Waters 996 PDA detector, Sunfire $\mathrm{C}_{18}$ column $3.5 \mu \mathrm{m} 4.6 \times 100 \mathrm{~mm}$, linear gradient over $14 \mathrm{~min}$ of 10 to $100 \% \mathrm{CH}_{3} \mathrm{CN}$ in $\mathrm{H}_{2} \mathrm{O} / 0.1 \%$ TFA, flow rate $1.0 \mathrm{~mL} / \mathrm{min}$. $t_{\mathrm{R}}$ [ethyl 2-(allyloxycarbonyloxyimino)-2-cyanoacetate] = $6.69 \mathrm{~min}$; purity $100 \%$.

Ethyl 2-(benzyloxycarbonyloxyimino)-2-cyanoacetate (19). The product was obtained as white crystals (2.76 g; 87\% yield) (m.p. 99-100 $\left.{ }^{\circ} \mathrm{C}\right)$. IR (KBr): 1802 (s, CO), 1743 (s, CO, ester) $\mathrm{cm}^{-1} .{ }^{1} \mathrm{H}-\mathrm{NMR}$ $\left(\mathrm{CDCl}_{3}\right): \delta 1.41\left(\mathrm{t}, 3 \mathrm{H},{ }^{3} \mathrm{~J}=7.2 \mathrm{~Hz}, \mathrm{CH}_{3}\right), 4.47\left(\mathrm{q}, 2 \mathrm{H},{ }^{3} \mathrm{~J}=7.2 \mathrm{~Hz}, \mathrm{CH}_{2}\right), 5.38\left(\mathrm{~s}, 2 \mathrm{H}, \mathrm{CH}_{2}\right), 7.40-7.44$ $(\mathrm{m}, 5 \mathrm{H}, \mathrm{Ar}-\mathrm{H}) .{ }^{13} \mathrm{C}-\mathrm{NMR}\left(\mathrm{CDCl}_{3}\right): \delta 14.17,64.80,72.57,106.63,129.06,129.23,129.63,131.23$, 133.59, 151.00, 156.76. Elemental analysis: Calcd for $\mathrm{C}_{13} \mathrm{H}_{12} \mathrm{~N}_{2} \mathrm{O}_{5}$ : C, 56.52; H, 4.38; N, 10.14 . 
Found: C, 56.23; H, 4.62; N, 10.41. The purity of 19 was determined after injection onto reverse-phase HPLC. Conditions: detection at $254 \mathrm{~nm}$ Waters 996 PDA detector, Sunfire $\mathrm{C}_{18}$ column $3.5 \mu \mathrm{m}$ $4.6 \times 100 \mathrm{~mm}$, linear gradient over $14 \mathrm{~min}$ of 10 to $100 \% \mathrm{CH}_{3} \mathrm{CN}$ in $\mathrm{H}_{2} \mathrm{O} / 0.1 \% \mathrm{TFA}$, flow rate $1.0 \mathrm{~mL} / \mathrm{min} . t_{\mathrm{R}}$ [ethyl 2-(benzyloxycarbonyloxyimino)-2-cyanoacetate] $=7.31 \mathrm{~min}$; purity $100 \%$.

\subsection{Synthesis of 4-(Ethoxycarbonylamino)benzoic Acid (21)}

A solution of ethyloxycarbonyl derivative $\mathbf{1 3}(\mathbf{a}-\mathbf{f})(1 \mathrm{mmol})$ in acetone $(10 \mathrm{~mL})$ was added dropwise to a stirring solution of 4-aminobenzoic acid $20(0.14 \mathrm{~g}, 1 \mathrm{mmol})$ and sodium carbonate $(0.32 \mathrm{~g}, 3 \mathrm{mmol})$ in acetone $(20 \mathrm{~mL})$ and $\mathrm{H}_{2} \mathrm{O}(10 \mathrm{~mL})$. After stirring overnight, the reaction mixture was concentrated under reduced pressure, and then extracted with $\mathrm{CH}_{2} \mathrm{Cl}_{2}(20 \mathrm{~mL})$ to remove the unreacted ethyloxycarbonyl derivatives. The reaction mixture was acidified with $1 \mathrm{~N} \mathrm{HCl}$ (detected with Congo red litmus paper) to give a white solid, which was filtered, washed with water several times, dried and then recrystallized (ethyl acetate/ $n$-hexane) to give a white solid. The purity of 21 was determined by reverse-phase HPLC. Conditions: detection at $220 \mathrm{~nm}$ (Waters 996 PDA detector); Sunfire $\mathrm{C}_{18}$ column $(3.5 \mu \mathrm{m} 4.6 \times 100 \mathrm{~mm})$; linear gradient over $14 \mathrm{~min}\left(10\right.$ to $100 \% \mathrm{CH}_{3} \mathrm{CN}$ in $\mathrm{H}_{2} \mathrm{O} / 0.1 \%$ TFA); flow rate $1.0 \mathrm{~mL} / \mathrm{min} . t_{\mathrm{R}}$ [4-(ethoxycarbonylamino)benzoic acid] $=4.18 \mathrm{~min}$. $\mathrm{IR}(\mathrm{KBr})$ : 3334 (w, NH), 3400-2500 (br, OH, acid), 1704 (s, CO, acidic), 1686 (s, CON) cm ${ }^{-1} .{ }^{1} \mathrm{H}-\mathrm{NMR}$ (DMSO): $\delta 1.24\left(\mathrm{t}, 3 \mathrm{H},{ }^{3} J=7.2 \mathrm{~Hz}, \mathrm{CH}_{3}\right), 4.13\left(\mathrm{q}, 2 \mathrm{H},{ }^{3} \mathrm{~J}=7.2 \mathrm{~Hz}, \mathrm{CH}_{2}\right), 7.54$ (d, 2H, $\left.{ }^{3} J=8.4 \mathrm{~Hz}, \mathrm{Ar}-\mathrm{H}\right), 7.82$ (d, $\left.2 \mathrm{H},{ }^{3} J=8.4 \mathrm{~Hz}, \mathrm{Ar}-\mathrm{H}\right), 9.93$ (s, $\left.1 \mathrm{H}, \mathrm{NH}\right) .{ }^{13} \mathrm{C}-\mathrm{NMR}$ (DMSO): $\delta$ 15.11, 61.11, 117.91, 124.91, $131.05,144.12,153.00,167.63$.

\subsection{HPLC Study of the Rate of Formation of Active Esters}

3.6.1. The Rate of Formation of the Active Ester of Fmoc-Val-OH 22 Using Oxime Carbonate Derivatives 13a, 17-19

A solution of Fmoc-Val-OH $22(0.0423 \mathrm{~g}, 0.125 \mathrm{mmol})$ and the oxime carbonate derivatives 13a, 17, 18 or $19(0.125 \mathrm{mmol})$ was dissolved in DMF $(2 \mathrm{~mL})$ in the presence of pyridine $(20 \mu \mathrm{L})$. The reaction was monitored by HPLC. Aliquots $(5 \mu \mathrm{L})$ were taken from the reaction mixture, diluted with ACN and detected by HPLC. Follow-ups were done at $30 \mathrm{~min}$ and at 1, 2, 4 and $24 \mathrm{~h}$ pre-activation. The percentages of OxymaPure ${ }^{\circledR}$ 12a, Fmoc-Val-OH 22, active ester 27, and alkyl or aryl ester 26 were determined by HPLC analysis of the diluted reaction mixture. Conditions: detection at $254 \mathrm{~nm}$ (Waters 996 PDA detector); Sunfire $\mathrm{C}_{18}$ column $(3.5 \mu \mathrm{m} 4.6 \times 100 \mathrm{~mm})$; linear gradient over $14 \mathrm{~min}$ (10 to $100 \% \mathrm{CH}_{3} \mathrm{CN}$ in $\mathrm{H}_{2} \mathrm{O} / 0.1 \% \mathrm{TFA}$ ); flow rate $1.0 \mathrm{~mL} / \mathrm{min}$. $t_{\mathrm{R}}$ [active ester] $=8.4 \mathrm{~min}$. The percentages of OxymaPure ${ }^{\circledR}$ 12a, Fmoc-Val-OH 22, active ester 27, and alkyl or aryl esters 26 are shown in Tables 4-7.

3.6.2. The Rate of Formation of the Active Ester of Fmoc-Phe-OH 23 Using Oxime Carbonate Derivatives $\mathbf{1 7}$ or $\mathbf{1 8}$

A solution of Fmoc-Phe-OH $23(0.0483 \mathrm{~g}, 0.125 \mathrm{mmol})$ and oxime carbonate derivative 17 or 18 $(0.125 \mathrm{mmol})$ was dissolved in DMF $(2 \mathrm{~mL})$ in the presence of pyridine $(20 \mu \mathrm{L})$. The reaction was monitored by HPLC. Aliquots $(5 \mu \mathrm{L})$ were taken from the reaction mixture, diluted with ACN and 
detected by HPLC. Follow-ups were done at $30 \mathrm{~min}$ and at 1, 2, 4 and $24 \mathrm{~h}$ pre-activation. The percentages of OxymaPure ${ }^{\circledR}$ (12a), Fmoc-Phe-OH 23, active ester 27 and alkyl ester 26 were determined by HPLC analysis of the diluted reaction mixture. Conditions: detection at $254 \mathrm{~nm}$ (Waters 996 PDA detector); Sunfire $\mathrm{C}_{18}$ column $(3.5 \mu \mathrm{m} 4.6 \times 100 \mathrm{~mm})$; linear gradient over 14 min (10 to $100 \% \mathrm{CH}_{3} \mathrm{CN}$ in $\mathrm{H}_{2} \mathrm{O} / 0.1 \% \mathrm{TFA}$ ); flow rate $1.0 \mathrm{~mL} / \mathrm{min}$. $t_{\mathrm{R}}$ [active ester] $=8.4 \mathrm{~min}$. The percentages of OxymaPure $^{\circledR}$ (12a), Fmoc-Phe-OH 23, active ester 27 and alkyl esters 26 are shown in Tables 8 and 9.

\subsubsection{The Rate of Formation of the Active Ester of Fmoc-Pro-OH 24 Using Oxime Carbonate Derivatives 17 or 18}

A solution of Fmoc-Pro-OH $24(0.0421 \mathrm{~g}, 0.125 \mathrm{mmol})$ and oxime carbonate derivative 17 or 18 $(0.125 \mathrm{mmol})$ was dissolved in DMF $(2 \mathrm{~mL})$ in the presence of pyridine $(20 \mu \mathrm{L})$. The reaction was monitored by HPLC. Aliquots $(5 \mu \mathrm{L})$ were taken from the reaction mixture, diluted with ACN and analyzed by HPLC. Follow-ups were done at $30 \mathrm{~min}$ and at 1, 2, 4 and $24 \mathrm{~h}$ pre-activation. The percentages of OxymaPure ${ }^{\circledR}$ (12a), Fmoc-Pro-OH 24, active ester 27 and alkyl ester 26 were determined by HPLC analysis of the diluted reaction mixture. Conditions: detection at $254 \mathrm{~nm}$ Waters 996 PDA detector, Sunfire $\mathrm{C}_{18}$ column $3.5 \mu \mathrm{m} 4.6 \times 100 \mathrm{~mm}$, linear gradient over 14 min of 10 to $100 \% \mathrm{CH}_{3} \mathrm{CN}$ in $\mathrm{H}_{2} \mathrm{O} / 0.1 \% \mathrm{TFA}$, flow rate $1.0 \mathrm{~mL} / \mathrm{min}$. $t_{\mathrm{R}}$ [active ester] $=8.2 \mathrm{~min}$. The percent of Oxyma 12a, Fmoc-Pro-OH 24, active ester 27 and alkyl esters 26 are shown in Tables 10 and 11.

\subsection{General Method for the Synthesis of Dipeptide Fmoc-Val-Ala-OMe $\mathbf{2 8}$}

A solution of Fmoc-Val-OH $22(0.339 \mathrm{~g}, 1 \mathrm{mmol})$ and the appropriate coupling reagent $(1 \mathrm{mmol})$ in DMF $(2 \mathrm{~mL})$ was cooled to $0{ }^{\circ} \mathrm{C}$ and treated dropwise with pyridine $(0.088 \mathrm{~mL}, 1.1 \mathrm{mmol})$. The reaction mixture was stirred for pre-activation at different times, depending on the conditions of the entry studied, and then treated with a solution of $\mathrm{H}$-Ala-OMe. $\mathrm{HCl}(0.139 \mathrm{~g}, 1 \mathrm{mmol})$ and pyridine $(0.088 \mathrm{~mL}, 1.1 \mathrm{mmol})$ in DMF $(1 \mathrm{~mL})$. The reaction mixture was stirred overnight. After dilution with $25 \mathrm{~mL}$ of ethyl acetate, the organic phase was washed with $5 \%$ citric acid $(3 \times 15 \mathrm{~mL})$, saturated aq. $\mathrm{NaHCO}_{3}(3 \times 15 \mathrm{~mL})$ and saturated aq. $\mathrm{NaCl}(3 \times 15 \mathrm{~mL})$, and then dried over anhydrous $\mathrm{Na}_{2} \mathrm{SO}_{4}$ and filtered. The solvent was removed with a rotary evaporator, and the residue was recrystallized from $\mathrm{CH}_{2} \mathrm{Cl}_{2}$ /hexane to give the dipeptide Fmoc-Val-Ala-OMe 28. The purity of $\mathbf{2 8}$ was by reverse-phase HPLC. Conditions: detection at $220 \mathrm{~nm}$ (Agilent 1200 PDA detector); Eclipse plus $\mathrm{C}_{18}$ column ( $3.5 \mu \mathrm{m} 4.6 \times 100 \mathrm{~mm})$; linear gradient over $14 \mathrm{~min}\left(10\right.$ to $100 \% \mathrm{CH}_{3} \mathrm{CN}$ in $\mathrm{H}_{2} \mathrm{O} / 0.1 \% \mathrm{TFA}$ ); flow rate $1.0 \mathrm{~mL} / \mathrm{min}$. $t_{\mathrm{R}}$ LL $[$ Fmoc-Val-Ala-OMe] $=8.32 \mathrm{~min}$. The results of coupling of Fmoc-Val-OH with H-Ala-OMe using different oximinocarbonate derivatives are shown in Table 12. ${ }^{1} \mathrm{H}-\mathrm{NMR}$ $\left(\mathrm{CDCl}_{3}\right): \delta 0.94-0.98\left(\mathrm{~m}, 6 \mathrm{H}, 2 \mathrm{CH}_{3}\right), 1.40\left(\mathrm{~d}, 3 \mathrm{H},{ }^{3} \mathrm{~J}=6.9 \mathrm{~Hz}, \mathrm{CH}_{3}\right), 2.10-2.11(\mathrm{~m}, 1 \mathrm{H}, \mathrm{CH}), 3.73$ (s, 3H, $\left.\mathrm{CH}_{3}\right), 3.90-4.00(\mathrm{~m}, 1 \mathrm{H}, \mathrm{CH}), 4.17-4.21(\mathrm{~m}, 1 \mathrm{H}, \mathrm{CH}), 4.34-4.43\left(\mathrm{~m}, 2 \mathrm{H}, \mathrm{CH}_{2}\right), 4.55-4.58$ (m, 1H, CH), 5.47-5.51 (m, 1H, NH), 6.42-6.45 (m, 1H, NH), 7.25-776 (m, 8H, Ar-H).

\section{Conclusions}

Protection of the amino group and activation of the carboxylic acid groups are the most important steps associated with peptide synthesis. A possible strategy is to use oxime carbonate derivatives to 
simultaneously protect the amino group as a carbamate derivative and activate the carboxylic acid group as an active oxime ester was performed. A detailed study is carried out to understand the scope and limitations of this method using different oxime carbonate derivatives. The efficiency of these derivatives depends on the nature of oxime carbonates and also on the nature of the amino acids. From our studies we determined that the new family of oximes are useful reagents for both $\mathrm{N}$-protection and activation of the protected amino acid. As a final conclusion from our studies, the ${ }^{i}$ BuocOXY compound 17 and AllocOXY compound 18 both give the best results for formation of the active ester with less alkyl ester formation, while the EtocOXY compund 13a gave the best results for the coupling step. The ZOXY reagent 19 might be not useful in either the activation or coupling steps.

\section{Acknowledgments}

In Spain, the work was partially financed by CICYT (CTQ2009-07758), the Generalitat de Catalunya (2009SGR 1024), the Institute for Research in Biomedicine Barcelona (IRB Barcelona) and the Barcelona Science Park. The Science and Technology Development Fund (STDF) in Egypt is thanked for its partial support through the Research Project TC/12/RSG/2012 (Proposal ID (4769)).

\section{References}

1. Groner, B. Peptides as Drugs. Discovery and Development; Wiley-VCH: Hoboken, NJ, USA, 2009; pp. 1-219.

2. Sewald, N.; Jakubke, H.-D. Peptides: Chemistry and Biology, 2nd ed.; Wiley-VCH: Hoboken, NJ, USA, 2009; pp. 63-162.

3. Edwards, C.M.B.; Cohen, M.A.; Bloom, S.R. Peptides as drugs. QJM 1999, 92, 1-4.

4. Han, S.-Y.; Kim, Y.-A. Recent development of peptide coupling reagents in organic synthesis. Tetrahedron 2004, 60, 2447-2467.

5. Montalbetti, C.A.G.N.; Falque, V. Amide bond formation and peptide coupling. Tetrahedron 2005, 61, 10827-10852.

6. El-Faham, A.; Albericio, F. Peptide Coupling Reagents, More than a Letter Soup. Chem. Rev. 2011, 111, 6557-6602.

7. Bergmann, M.; Zervas, L. Über ein allgemeines Verfahren der Peptid-Synthese. Ber. Deut. Chem. Ges. 1932, 65B, 1192-1202.

8. Guibé, F. Allylic Protecting Groups and Their Use in a Complex Environment Part II: Allylic Protecting Groups and their Removal through Catalytic Palladium $\pi$-Allyl Methodology. Tetrahedron 1998, 54, 2967-3042.

9. Rajesh, K.P.; Dagade, S.P.; Dongare, M.K.; Kumar, P. Synthesis of Carbamates Using Yttria-Zirconia Based Lewis Acid Catalyst. Synth. Commun. 2003, 33, 4019-4027.

10. Tessier, M.; Albericio, F.; Pedroso, E.; Grandas, A.; Eritja, R.; Giralt, E.; Granier, C.; van Rietschoten, J. Amino-acids condensations in the preparation of $\mathrm{N}$ alpha-9-fluorenylmethyloxycarbonylamino-acids with 9-fluorenylmethylchloroformate. Int. J. Pept. Protein Res. 1983, 22, 125-128.

11. Sennyey, G.; Barcelo, G.; Senet, J.-P. Diallyl dicarbonate. A convenient reagent for the synthesis of allyl carbamates. Tetrahedron Lett. 1987, 28, 5809-5810. 
12. Stevens, C.M.; Watanabe, R. Amino Acid Derivatives. I. Carboallyloxy Derivatives of $\alpha$-Amino Acids. J. Am. Chem. Soc. 1950, 72, 725-727.

13. Sennyey, G.; Borcelo, G.; Senet, J.-P. Synthesis and use of dibenzylpyrocarbonate: preparation of dipeptide free $n$-benzyloxycarbonyl glycine. Tetrahedron Lett. 1986, 27, 5375-5376.

14. Wünsch, E.; Graf, W.; Keller, O.; Keller, W.; Wersin, G. On the Synthesis of Benzyloxycarbonyl Amino Acids. Synthesis 1986, 1986, 958-960.

15. Paquet, A. Introduction of 9-fluorenylmethyloxycarbonyl, trichloroethoxycarbonyl, and benzyloxycarbonyl amine protecting groups into O-unprotected hydroxyamino acids using succinimidyl carbonates. Can. J. Chem. 1982, 60, 976-980.

16. Chinchilla, R.; Dodsworth, D.J.; Nájera, C.; Soriano, J.M. New Polymer-Supported Allyloxycarbonyl (Alloc) and Propargyloxycarbonyl (Proc) Amino-Protecting Reagents. Synlett 2003, 2003, 809-812.

17. Carpino, L.A.; Han, G.Y. The 9-Fluorenylmethoxycarbonyl Amino-Protecting Group. J. Am. Chem. Soc. 1972, 57, 3404-3409.

18. Cruz, L.J.; Beteta, N.G.; Ewenson, A.; Albericio, F. "One-Pot" Preparation of N-Carbamate Protected Amino Acids via the Azide. Org. Process Res. Dev. 2004, 8, 920-924.

19. Barcelo, G.; Senet, J.-P.; Sennyey, G. 1,2,2,2-Tetrachlorethyl tert-butyl carbonate: A simple and efficient reagent for the tert-butoxycarbonylation of amines and amino acids. J. Org. Chem. 1985, 50, 3951-3953.

20. Barcelo, G.; Senet, J.-P.; Sennyey, G.; Bensoam, J.; Loffet, A. Alkyl 1-Chloroalkyl Carbonates: Reagents for the Synthesis of Carbamates and Protection of Amino Groups. Synthesis 1986, 1986, 627-632.

21. Henklein, P.; Heyne, H.-V.; Halatsch, W.R.; Niedrich, H. 5-Norbornene-2,3-dicarboximido Carbonochloridate. A New Stable Reagent for the Introduction of Amino-Protecting Groups. Synthesis 1987, 1987, 166-167.

22. Schön, I.; Kisfaludy, L. 9-Fluorenylmethyl Pentafluorophenyl Carbonate as a Useful Reagent for the Preparation of $N$-9-Fluorenylmethyloxycarbonylamino Acids and their Pentafluorophenyl Esters. Synthesis 1986, 1986, 303-305.

23. Ramapanicker, R.; Baig, N.B.R.; De, K.; Chandrasekaran, S. One-pot protection and activation of amino acids using pentafluorophenyl carbonates. J. Pept. Sci. 2009, 15, 849-855.

24. Ramapanicker, R.; Rajasekaran, S.; Gupta, R.; Chandrasekaran, S. Simultaneous Protection and Activation of Amino Acids Using Propargyl Pentafluorophenyl Carbonate. Org. Lett. 2006, 8, 1933-1936.

25. Hayakawa, Y.; Wakabayashi, S.; Kato, H.; Noyori, R. The allylic protection method in solid-phase oligonucleotide synthesis. An efficient preparation of solid-anchored DNA oligomers. J. Am. Chem. Soc. 1990, 112, 1691-1696.

26. Ibrahim, T.S.; Tala, S.R.; El-Feky, S.A.; Abdel-Samii, Z.K.; Katritzky, A.R. Benzotriazole reagents for the syntheses of Fmoc, Boc and Alloc protected amino acids. Synlett 2011, 2011, 2013-2016.

27. Subirós-Funosas, R.; Prohens, R.; Barbas, R.; El-Faham, A.; Albericio, F. Oxyma: An Efficient Additive for Peptide Synthesis to Replace the Benzotriazole-Based HOBt and HOAt with a Lower Risk of Explosion. Chem. Eur. J. 2009, 15, 9394-9403. 
28. Wehrstedt, K.D.; Wandrey, P.A.; Heitkamp, D. Explosive properties of 1-hydroxybenzotriazoles. J. Hazard. Mater. 2005, A126, 1-7.

29. Subiros-Funosas, R.; Acosta, G.A.; El-Faham, A.; Albericio, F. Microwave irradiation and COMU: A Superior tool for solid phase peptide synthesis. Tetrahedron Lett. 2009, 50, 6200-6202.

30. El-Faham, A.; Albericio, F. COMU: A Third Generation of Uronium-Type Based Coupling Reagent. J. Pept. Sci. 2010, 16, 6-9.

31. El-Faham, A.; Subiros-Funosas, R.; Albericio, F. A novel family of onium salts based upon isonitroso Meldrum's acid proves useful as peptide coupling reagents. Eur. J. Org. Chem. 2010, 2010, 3641-3649.

32. Subiros-Funosas, R.; El-Faham, A.; Albericio, F. PyOxP and PyOxB: the Oxyma-based novel family of phosphonium salts. Org. Biomol. Chem. 2010, 8, 3665-3673.

33. Subiros-Funosas, R.; El-Faham, A.; Albericio, F. Use of Oxyma as pH modulatory agent to be used in the prevention of base-driven side reactions and its effect on 2-chlorotrityl chloride resin. Biopolymers 2012, 98, 89-97.

34. Kamińki, Z.J.; Kolesińska, B.; Sabatino, G.; Chelli, M.; Rovero, P.; Blasz, M.; Glówka, M.L.; Papini, A.M. N-Triazinylammonium Tetrafluoroborates. A New Generation of Efficient Coupling Reagents Useful for Peptide Synthesis. J. Am. Chem. Soc. 2005, 127, 16912-16920.

35. Khattab, S.N.; Subirós-Funosas, R.; El-Faham, A.; Albericio, F. Oxime Carbonates: Novel Reagents for the Introduction of Fmoc and Alloc Protecting Groups, Free of Side Reactions. Eur. J. Org. Chem. 2010, 17, 3275-3280.

36. Khattab, S.N.; Subirós-Funosas, R.; El-Faham, A.; Albericio, F. Cyanoacetamide-based oxime carbonates: an efficient, simple alternative for the introduction of Fmoc with minimal dipeptide formation. Tetrahedron 2012, 68, 3056-3062.

Sample Availability: Samples of the most part of the compounds are available from the authors.

(C) 2012 by the authors; licensee MDPI, Basel, Switzerland. This article is an open access article distributed under the terms and conditions of the Creative Commons Attribution license (http://creativecommons.org/licenses/by/3.0/). 